\title{
Nutrient Digestibility and Performance of Male Pelung Chicken Fed Rice Bran- Based Ration Supplemented with Lime (Citrus aurantifolia) Juice
}

\author{
I. Mangisah*, B. Sukamto, H. I. Wahyuni, I. Estiningdriati, W. Saputro, \& L. Krismiyanto \\ Faculty of Animal and Agriculture Sciences, Diponegoro University \\ Semarang 50275 Central Java, Indonesia \\ (Received 29-10-2015; Reviewed 07-01-2016; Accepted 29-03-2016)
}

\begin{abstract}
Rearing Pelung chicken in Indonesia, in general, uses a ration with a high proportion of rice bran, even up to $60 \%$. Considering the high contents of fiber, lignin, and phytic acid, feeding a high portion of rice bran will decrease nutrient digestibility. This study was aimed to evaluate the effect of lime juice supplementation of a rice bran-based ration on the utilization of nutrients in male Pelung chicken. Sixty four of $\mathbf{1 2}$ weeks old male Pelung chickens were used in the present experiment and assigned into a completely randomized block design. The treatments were supplementation of the ration with lime juice at the levels of $0,1,2$, and $3 \mathrm{~mL} / 100 \mathrm{~g}$. Parameters measured were feed and nutrients consumption, protein, fat, and fiber digestibilities, apparent metabolizable energy (AME), rate of passage, feed conversion ratio (FCR), and daily body weight gain. The results showed that the supplementation of lime juice in the ration did not affect feed and nutrient consumption, but significantly $(P<0.05)$ increased the digestibilities of protein, fat and fiber, AME, rate of passage, FCR and daily body weight gain. However, supplementation of 2 or $3 \mathrm{~mL}$ lime juice in the ration resulted in similar values of AME, and protein, fat and fiber digestibilities, and both levels of supplementation produced better protein and fat digestibilities, and AME when compared to the other treatments. It could be concluded that supplementation of $3 \mathrm{~mL}$ lime juice in the ration increased the digestion processes in the gastrointestinal and increased daily weight gain of male Pelung chicken.
\end{abstract}

Key words: male Pelung chicken, lime juice, nutrient digestibility, daily body weight gain

\section{ABSTRAK}

Pemeliharaan ayam pelung di Indonesia pada umumnya menggunakan ransum dengan proporsi dedak padi yang tinggi. Porsi dedak padi mencapai $60 \%$, namun berhubung dedak padi mengandung serat kasar, lignin, dan asam fitat yang tinggi menyebabkan kecernaan nutrien rendah. Penelitian ini bertujuan untuk mengevaluasi pengaruh penambahan sari jeruk nipis dalam ransum berbasis dedak padi terhadap kecernaan nutrien pada ayam pelung jantan. Ayam pelung jantan umur 12 minggu sebanyak 64 ekor, dialokasikan ke dalam rancangan acak kelompok. Perlakuan yang diberikan adalah suplementasi jus jeruk nipis pada ransum dengan level 0, 1, 2, dan $3 \mathrm{~mL} / 100$ g. Parameter yang diukur adalah konsumsi ransum dan nutrien, kecernaan protein, lemak, serat, energi metabolis semu, laju digesta, konversi ransum, dan pertambahan bobot badan harian. Hasil penelitian menunjukkan bahwa penambahan jeruk nipis tidak berpengaruh nyata terhadap konsumsi ransum dan nutrien, tetapi nyata $(P<0,05)$ meningkatkan kecernaan protein, lemak, dan serat, energi metabolis semu, laju digesta, konversi ransum, dan pertambahan bobot badan harian. Penambahan 2 atau $3 \mathrm{~mL}$ jus jeruk nipis dalam ransum tidak menyebabkan adanya perbedaan energi metabolis semu, kecernaan protein, lemak dan serat, tetapi kecernaan protein dan lemak lebih baik dibandingkan perlakuan lainnya. Sebagai kesimpulan dapat dinyatakan bahwa penambahan 3 $\mathrm{mL}$ jus jeruk nipis memperbaiki proses pencernaan nutrien dan meningkatkan pertambahan bobot badan harian pada ayam pelung jantan.

Kata kunci: ayam pelung jantan, jeruk nipis, kecernaan nutrien, pertambahan bobot badan harian

*Corresponding author:

E-mail: istnamangisah@yahoo.co.id 


\section{INTRODUCTION}

Pelung chicken is an indigenous chicken originating from Cianjur, West Java, Indonesia, which is usually reared as a fancy chicken with a very good sound of crow. Although Pelung chickens at first were kept and bred for fancy due to their sound of crows, by looking at their exterior performance it is considered that those chickens are very potential to be developed as a more economically valuable commodity. However, the problems of feed supply either quality or quantity as well as feed cost are often to be an obstacle for small holder of Pelung chicken farming. Farmers are mostly fed the chickens by mixing commercial concentrate with rice bran in order to achieve a low feed cost. A portion of rice bran used in the ration is sometime extremely high, up to $50 \%$ (Hidayat et al., 2014). There are numerous weaknesses of feeding high portion of rice bran to the poultry, including Pelung chicken. It is well known that rice bran contains high crude fiber, lignin, and phytic acid which can detrimental to the productive performance via its negative effects on nutrients digestibility. Ridwan et al. (2005) stated that rice bran contain $73.85 \%$ neutral detergent fiber (NDF) and $35.04 \%$ acid detergent fiber (ADF). The high level of dietary crude fiber affects the rate of passage of the digesta, hence providing impact on either nutrients digestibility or absorption. The faster the rate of passage of the digesta the fewer the nutrients to be absorbed and utilized by the body, and vice versa. There are several factors that have been known to overcome the problems of low digestibility. Acidifier such as citric acid, is one of substances that is possible to be implemented to improve nutrients digestibility.

Citric acid has beneficial effects, such as lowering the $\mathrm{pH}$ value of digestive tract of poultry. Low intestinal $\mathrm{pH}$ is greatly possible to suppress the growth of pathogenic microorganisms, stimulate digestive enzymes, and improve the health condition of the digestive tract. This phenomenon leads to the increase in nutrient utilization and ultimately improves productive performance. Previous study indicated that feeding 3\% of citric acid would increase nutrient digestibility and apparent metabolizable energy (Martinez-Ameaqua et al., 2006). According to Rafacz-Livingston et al. (2005), dietary supplementation of citric acid at a range of $2 \%$ to $6 \%$ and fed to cross-bred chicken of Colombia hen and Hampshire rooster, increased body weight gain and feed efficiency, but decreased feed conversion ratio. Van Antwerpen et al. (2007) reported that the addition of $2 \%$ organic citric acid in the ration significantly increased protein and fiber digestibilities in broiler chickens. It is clear that dietary inclusion of acidifier has a positive effect on the growth of chickens through the lowering $\mathrm{pH}$ of the digestive tract. Acidic condition of the digestive tract reduced pathogenic bacteria since they were succeptible to low pH atmosphere (Ghazalah et al., 2011). Therefore, acidifier at the same time would function as an antimicrobial agent. On the other hand, Ghazalah et al. (2011) also stated that the reduction of buffering capacity has a positive relation to the digestibility coefficient of protein, fat, and fiber, as well as the energy metabolism.
The natural material containing high citric acid is lime fruit. Maghfiroh et al. (2012) showed that $100 \mathrm{~g}$ of lime fruit contains $7 \%$ citric acid, $27 \mathrm{mg}$ vitamin $\mathrm{C}$, and $0.04 \mathrm{mg}$ vitamin B1. Citric acid content of lime fruit is an useful organic acid acidifier which contributes to the acidifying the digesta in the gastrointestinal tract and affects intestinal $\mathrm{pH}$, and the rate of passage because of the decreased pathogenic bacterial population. All of these positive phenomena occured in the digestive tract would bring about the increase in dietary protein digestibilty and nitrogen retention.

Optimization of the digestive tract and process of digestion conditions would be an entrance of the nutrient utilization that should be highly accommodated. Ecosystem of the digestive tract of the poultry is a very important determinant for the improvement of the nutrient digestibility, animal health, and eventually the bird's performances. The study was conducted to evaluate the effect of lime juice supplementation in the ration on protein utilization and performance of 12 weeks old of male Pelung chicken.

\section{MATERIALS AND METHODS}

The experimental animals used in the present study were 64 male Pelung chickens at the age of 12 weeks, with an average body weight of $1,084.44 \pm 210.89 \mathrm{~g}$. The basal ration was composed of $14.57 \%$ protein and 2,353.91 kcal/kg metabolizable energy (Table 1).

The research was assigned in a completely randomized block design (CRBD) with 4 treatments and 4 groups as replication. Each group consisted of 4 birds of male Pelung chickens. The grouping was based on the body weight as follows:

$\mathrm{G} 1=740-910 \mathrm{~g}$ with an average of $835.51 \pm 49.48 \mathrm{~g}$ $\mathrm{G} 2=910-1,080 \mathrm{~g}$ with an average of $985.69 \pm 42.04 \mathrm{~g}$

Table 1. Basal rations and nutrient content (as fed weight basis)

\begin{tabular}{|c|c|}
\hline Feedstuff & Composition $(\%)$ \\
\hline Rice bran & 60 \\
\hline Concentrate CP 521 Merck $^{\mathrm{a}}$ & 35 \\
\hline Mineral mix ${ }^{b}$ & 5 \\
\hline Total & 100 \\
\hline \multicolumn{2}{|l|}{ Nutritional content $(\%)$ : } \\
\hline Metabolizable energy (kcal/kg) & $2,353.91$ \\
\hline Crude protein (\%) & 14.57 \\
\hline Crude fat $(\%)$ & 6.57 \\
\hline Crude fiber (\%) & 21.37 \\
\hline Calcium (\%) & 0.45 \\
\hline Phosphorus (\%) & 0.34 \\
\hline
\end{tabular}

Note:

${ }^{a}$ Nutritional content of concentrate CP 521 Merck: ash=32\%; crude protein $=30 \%-32 \%$; crude fat $=3 \%$; crude fiber $=8 \%$; Ca= $10 \%$; $P=1.1 \%$. bMineral mix composition, each $10 \mathrm{~kg}$ contains: Vitamin $\mathrm{A}=12,000,000$ IU; Vitamin D3=2,000,000 IU; Vitamin E=8,000 IU; Vitamin K=2,000 mg; Vitamin B1=2,000 mg; Vitamin B2=5,000 mg; Vitamin B6=500 mg; Vita$\min \mathrm{B} 12=12,000 \mu \mathrm{g}$; Vitamin $\mathrm{C}=25,000 \mathrm{mg}$; Calcium-D-panthothenate= 6,000 mg; Niacin= 40,000 mg; Choline chloride=10,000 mg; Methionine= $30,000 \mathrm{mg}$; Lysine=30,000 mg; Manganese $=120,000 \mathrm{mg}$; Iron= 20,000 mg; Iodine $=200 \mathrm{mg}$; Zinc $=100,000 \mathrm{mg}$; Cobalt $=200 \mathrm{mg}$; Copper $=4,000 \mathrm{mg}$; Zinc Bacitracin= 21,000 mg; Excipient q.s $=10,000 \mathrm{mg}$. 
$\mathrm{G} 3=1,080-1,250$ with an average of $1,160.63 \pm 55.69 \mathrm{~g}$ $\mathrm{G} 4=1,250-1,420$ with an average of 1,369.06 $\pm 65.97 \mathrm{~g}$

The treatments were based on the level of lime juice supplementation to the basal diet were given for 4 weeks as follows:

$\mathrm{T} 0=$ no supplementation of lime juice

$\mathrm{T} 1$ = supplementation of $1 \mathrm{~mL}$ lime juice $/ 100 \mathrm{~g}$ ration

$\mathrm{T} 2$ = supplementation of $2 \mathrm{~mL}$ lime juice $/ 100 \mathrm{~g}$ ration

$\mathrm{T} 3$ = supplementation of $3 \mathrm{~mL}$ lime juice/100 $\mathrm{g}$ ration

Parameters observed were daily feed intake, protein, fat, fiber consumptions, and metabolizable energy, rate of passage, feed conversion ratio, and body weight gain. Digestibility coefficient of nutrient was measured at the end of the experiment using total collection method, and computed according to Sibbald \& Wolynetz (1984), as follows:

Digestibility coefficient of protein $($ DCP,$\%)=[($ Crude protein consumption - Excreta's protein)/Crude protein consumption] x $100 \%$

Digestibility coefficient of fiber $(\%)=[($ Crude fiber consumption - Excreta's fiber)/Crude fiber consumption] $\mathrm{x}$ $100 \%$

Digestibility coefficient of fat $(\%)=[($ Crude fat consumption - Excreta's fat)/Crude fat consumption] x 100\% Apparent metabolizable energy (AME, kkal/kg)= [(Gross energy consumption - Excreta's gross energy)/ Feed consumption] x 1000
Feed conversion ratio $=$ Feed consumption/Body weight gain

Rate of passage measurement was recorded based on the total collection method combined with indicator according to Indreswari et al. (2009).

\section{RESULTS}

\section{Nutrient Utilization}

Protein, fat, and crude fiber consumptions were not affected by the levels of lime juice supplementation in the ration (Table 2) since feed consumptions were same among treatments (Table 3). However, supplementation of lime juice significantly $(\mathrm{P}<0.05)$ increased the digestibilities of nutrients (crude protein, crude fat, and crude fiber). When the level of lime juice supplementation in the rice bran-based ration increased to $2 \mathrm{~mL}$ (T2) and $3 \mathrm{~mL}$ (T3) the digestibility coefficients of protein and fat, and apparent metabolizable energy were significantly higher than control (T0). Digestibility coefficient of protein improved to be higher by $4 \%$ to $5 \%$ when the level of lime juice supplementation in the ration increased (T2 and T3) as compared to control i.e., the ration without lime juice supplementation (T0). The significantly $(\mathrm{P}<0.05)$ slower rate of passage and the significant increase in digestibility coefficient of fiber were only found in the treatment of the highest level of lime

Table 2. Average of nutrient consumption, digestibility coefficient of protein, fat, fiber and apparent metabolizable energy of rice bran-based ration supplemented with lime juice fed to 12 weeks old male pelung chicken

\begin{tabular}{|c|c|c|c|c|}
\hline \multirow{2}{*}{ Parameter } & \multicolumn{4}{|c|}{ Treatments } \\
\hline & T0 & $\mathrm{T} 1$ & $\mathrm{~T} 2$ & T3 \\
\hline Protein consumption $(\mathrm{g})$ & $14.28 \pm 1.08$ & $15.16 \pm 2.15$ & $14.42 \pm 3.28$ & $14.76 \pm 3.34$ \\
\hline Fat consumption (g) & $6.44 \pm 1.56$ & $6.84 \pm 1.72$ & $6.51 \pm 1.58$ & $6.65 \pm 1.14$ \\
\hline Fiber consumption $(\mathrm{g})$ & $20.94 \pm 1.26$ & $22.24 \pm 1.37$ & $21.16 \pm 0.98$ & $21.64 \pm 1.15$ \\
\hline Rate of passage (min) & $183.60 \pm 5.74^{\mathrm{b}}$ & $205.58 \pm 10.04^{\mathrm{ab}}$ & $203.28 \pm 5.75^{\mathrm{ab}}$ & $221.23 \pm 10.36^{a}$ \\
\hline Digestibility coefficient of protein (\%) & $72.79 \pm 1.18^{\mathrm{b}}$ & $73.65 \pm 1.24^{b}$ & $76.90 \pm 1.05^{\mathrm{a}}$ & $77.43 \pm 1.74^{\mathrm{a}}$ \\
\hline Digestibility coefficient of fat (\%) & $71.85 \pm 2.66^{\mathrm{b}}$ & $74.40 \pm 2.00^{\mathrm{b}}$ & $83.87 \pm 2.66^{\mathrm{a}}$ & $82.06 \pm 2.70^{\mathrm{a}}$ \\
\hline Digestibility coefficient of fiber (\%) & $19.18 \pm 2.35^{\mathrm{b}}$ & $22.59 \pm 2.14^{\mathrm{ab}}$ & $23.16 \pm 2.37^{\mathrm{ab}}$ & $25.18 \pm 2.15^{\mathrm{a}}$ \\
\hline Apparent metabolizable energy $(\mathrm{kcal} / \mathrm{kg})$ & $2401.99 \pm 5.30^{\mathrm{b}}$ & $2420.90 \pm 4.56^{\mathrm{b}}$ & $2532.67 \pm 5.08^{\mathrm{a}}$ & $2553.60 \pm 5.86^{\mathrm{a}}$ \\
\hline
\end{tabular}

Note: Means in the same row with different superscripts differ significantly $(\mathrm{P}<0.05)$. T0 = no supplementation of lime juice; $1=$ supplementation of 1 $\mathrm{mL}$ lime juice/100 $\mathrm{g}$ ration; $\mathrm{T} 2=$ supplementation of $2 \mathrm{~mL}$ lime juice/100 $\mathrm{g}$ ration; $\mathrm{T} 3=$ supplementation of $3 \mathrm{~mL}$ lime juice/100 $\mathrm{g}$ ration

Table 3. Average of feed consumption, daily weight gain, and feed conversion ratio of 12 weeks old male pelung chicken rice fed bran-based ration supplemented with lime juice

\begin{tabular}{|c|c|c|c|c|}
\hline \multirow{2}{*}{ Parameter } & \multicolumn{4}{|c|}{ Treatments } \\
\hline & T0 & $\mathrm{T} 1$ & $\mathrm{~T} 2$ & T3 \\
\hline Feed consumption (g/bird/d) & $98.00 \pm 5.90$ & $104.08 \pm 6.41$ & $99.03 \pm 4.59$ & $101.27 \pm 5.39$ \\
\hline Initial body weight (g/bird) & $998.50 \pm 12.44$ & $1058.66 \pm 13.09$ & $1095.54 \pm 13.52$ & $1085.45 \pm 11.64$ \\
\hline Final body weight (g/bird) & $1331.10 \pm 10.05^{c}$ & $1400.46 \pm 12.44^{\mathrm{b}}$ & $1446.38 \pm 11.88^{\mathrm{ab}}$ & $1481.65 \pm 9.05^{\mathrm{a}}$ \\
\hline Cummulative body weight gain (g/bird) & $332.60 \pm 7.12^{c}$ & $341.80 \pm 8.80^{\mathrm{b}}$ & $350.84 \pm 9.10^{\mathrm{ab}}$ & $396.20 \pm 7.27^{\mathrm{a}}$ \\
\hline Daily body weight gain (g/bird/d) & $10.85 \pm 0.71^{\mathrm{b}}$ & $12.95 \pm 1.16^{\mathrm{ab}}$ & $12.53 \pm 0.89^{\mathrm{ab}}$ & $14.15 \pm 1.69^{\mathrm{a}}$ \\
\hline Feed conversion ratio & $9.02 \pm 4.08^{\mathrm{b}}$ & $8.04 \pm 4.70^{\mathrm{ab}}$ & $7.90 \pm 5.04^{\mathrm{ab}}$ & $7.16 \pm 4.82^{\mathrm{a}}$ \\
\hline
\end{tabular}

Note: Means in the same row with different superscripts differ significantly $(\mathrm{P}<0.05)$. T0 = no supplementation of lime juice; T1 = supplementation of 1 $\mathrm{mL}$ lime juice/100 $\mathrm{g}$ ration; $\mathrm{T} 2=$ supplementation of $2 \mathrm{~mL}$ lime juice/100 $\mathrm{g}$ ration; $\mathrm{T} 3=$ supplementation of $3 \mathrm{~mL}$ lime juice/100 $\mathrm{g}$ ration 
juice supplementation (T3). However, both parameters (rate of passage and fiber digestibility) among other three treatments (T0, T1, and T2) were not significantly different.

\section{Growth Performance}

Feed consumption was not affected by the supplementation of lime juice in the ration, but the other parameters such as final body weight, body weight gain either cummulative or daily measurement, and feed conversion ratio were significantly $(\mathrm{P}<0.05)$ affected by the lime juice supplementation (Table 3). Final body weight and cummulative body weight gain were significantly $(\mathrm{P}<0.05)$ improved by the lime juice supplementation with the highest value was found at the level of $3 \mathrm{~mL}$ lime juice supplementation (T3). The different phenomena were found for daily body weight gain and feed conversion ratio. Body weight gain significanly increased $(\mathrm{P}<0.05)$ but feed conversion ratio was lower with supplementation of $3 \mathrm{~mL}$ lime juice (T3) as compared to control group without lime juice supplementation (T0).

\section{DISCUSSION}

\section{Nutrient Utilization}

Supplementation of lime juice in the ration did not interfere with feed consumption since this parameter indicated the same value among treatments (Table 3). However, the effect of lime juice supplementation was more profound on nutrient digestibilities. The digestibilities of nutrients in the experimental Pelung chickens supplemented with lime juice at the levels of $2 \mathrm{~mL} / 100 \mathrm{~g}$ ration (T2) and $3 \mathrm{~mL} / 100 \mathrm{~g}$ ration (T3) were significantly higher as compared to those supplemented with lime juice at the level of $1 \mathrm{~mL} / 100 \mathrm{~g}$ ration (T1). It is known that lime juice supplementation decreases the $\mathrm{pH}$ of the digestive track, especially the proventriculus and the uper intestine, thus stimulating the digestive enzyme activity. The increases in the metabolizable energies in T2 and T3 were atributable to the the improved digestive process due to the supplementation of lime juice. Acidification of the stomach with favourable affects on 'pepsinogen-pepsin' conversion and deloading the chymus from microorganisms (depending on $\mathrm{pH}$-range and type of microorganism). Organic acids with higher $\mathrm{pKa}$ values are more effective preservatives and their antimicrobial efficacy is generally improved with the increasing of chain length and degree of unsaturation. The blends of acids represents an array of $\mathrm{pKa}$ with a broader spectrum of activity (Huyghebaert, 2005).

Supplementation of lime juice in the ration was also reported to improve the balance of bacterial population in the digestive tract. According to Huyghebaert (2005), the effect of acids might induce a more balanced intestinal flora by reducing the proliferation of some pathogenic bacteria. The improved balance of bacterial population is suggested to be correlated with the change in the hydrogen ions. The decreased $\mathrm{pH}$ of the digestive tract will support the growth and development of beneficial bacteria more than pathogenic bacteria. This condition can ensure the better digestive tract health and thus provided a positive impact on the utilization of substrate (especially protein) by the body. The higher protein availability was closely indicated by the increased protein digestibility and supported by the improved fiber digestibility and also the slower rate of passage (Table 2).

The citric acid content of the lime juice is able to change the atmosphere of the digestive tract into acidic condition, hence lowering the $\mathrm{pH}$ in the proventriculus, ventriculus, and uper intestine, so that the enzymes in these digestive tracts actively work to digest the dietary protein. As it was briefly discussed in the previous paragraph that the acidic condition also simultaneously suppressed the growth of pathogenic bacteria that could ultimately improve the health of digestive tract which in turn would also affect nutrient digestibility. Based on the reseach of Kurniagung et al. (2012), dietary of 1.5-4.5 mL lime juice in ration Magelang ducks male significantly lowered population of coliform bacteria. Supplementation of 3\% citric acid increased nutrient digestibility and apparent metabolizable energy. Ghazalah et al. (2011) reported that the supplementation of acidifier had a positive influence on the growth of chickens due to the lowering $\mathrm{pH}$ of the digestive tract so that pathogenic bacteria that were not resistant to the low $\mathrm{pH}$ could be reduced. This suggested that acidifier could function as an antimicrobial lowering the population of pathogenic bacteria related to the improvement of digestibility values of crude protein, fat, and crude fiber, and metabolizable energy as found in the present study. Gastrointestinal acidification brings about the impact on both changing the activation of the enzyme that converts pepsinogen into pepsin and absorb nutrients that have been flatten by microorganisms (depend on $\mathrm{pH}$ range and types of microorganisms). Dietary addition of $3 \%$ citric acids increased nutrient digestibility and apparent metabolizable energy (Martinez-Ameaqua et al., 2006). Van Antwerpen et al. (2007) stated that the feeding effect of organic citric acid at the level of $2 \%$ significantly increased protein and crude fiber digestibilities.

\section{Growth Performance}

Supplementation of lime juice can increase the efficiency of nutrients utilization as indicated by the same nutrients consumption but higher nutrients digestibility (Table 2). The beneficial effect of lime juice as a acidifier was further supported by the data of increased body weight gain with lower feed conversion ratio (Table 3). Feed conversion ratio in T2 and T3 treatments were higher when compared to those in T0 and T1. This suggested that the beneficial effect of lime juice as an acidifier was correlated with the improved efficiency of nutrients utilization. This result was consistent with the finding of Deepa et al. (2011) that supplementation of citric acid could improve body weight gain and feed convertion ratio.

The decreased $\mathrm{pH}$ of the digestive tract due to the supplementation of lime juice ultimately increased the digestibility of crude protein because lower $\mathrm{pH}$ of 
digestive tract is a favourable condition to support the activity of digestive enzymes. Digestive enzymes, especially pepsin has an important role in protein digestion. The increased protein digestibility (Table 2) contributes a higher amino acid availability for the synthesis of body tissue. The higher the synthesis of body tissue the higher the increase in body weight gain and improved performance in general. The higher nutrient digestibility, the higher nutrient absorption and utilization for the growth of body tissue. Body weight gain is closely related to the increased nutrient digestibility, and the case in the present study was indicated by the increased protein digestibility in the experimental Pelung chickens supplemented with $2 \mathrm{~mL}$ and $3 \mathrm{~mL}$ of lime juice, respectively. The increased protein digestibility improved body weight gain. The present result was consistent with the report of Rafacz-Livingston et al. (2005) that the supplementation of citric acid by $2 \%$ to $6 \%$ in the rations increased body weight gain, feed efficiency, and feed conversion ratio in chickens.

The improved performance of male Pelung chicken supplemented with lime juice could be due to the presence of flavonoid in lime juice. Lime juice contains flavonoid which has a positive effect on growth (Onyeagba et al., 2004). Chemical property of flavonoid could inhibit the growth of virus, bacteria, and fungi. The more specific effect is that active compound of flavonoid has the direct role as an antibacterial to reduce bacterial activity. Therefore, supplementation of lime juice containing flavonoid increased animal health and finally resulted in the higher body weight gain as compared to control. Barrett et al. (1999) supported the present result that supplementation of citric acid increased the percentage weight of lymphoid organs (bursa fabricius and thymus) as an indicator of body health. Feeding citric acid in broiler chicken even with low dietary protein level (19\%) could increase the body health indicated by antibody titer (Malkoski et al., 2001).

Organic acids are among alternative growth promoters that are being used to stimulate growth performance in poultry (Biswas et al., 2013; Mohamed et al., 2013). Previous study demonstrated that supplementation of organic acids in the ration increased growth performance, improved gut morphology, reduced diseases, and overcame some management problems of broiler chikens (Gunal et al., 2006). Abd El-Hakim et al. (2009) found that supplementation of organic acids in the ration of broiler improved FCR and growth performance. Abdel-Fattah et al. (2008) stated that broiler chicks fed dietary organic acids had superior improvement in live body weight, body weight gain, and FCR compared to those of unsupplemented diet. Feed conversion ratio of birds supplemented with lime juice at the level of 0.3 $\mathrm{mL}$ (T3) was lower than that of without lime juice supplementation (T0). The present result can be compromized with the study of Iqbal et al. (2008) who reported that the birds fed diet supplemented with organic acids showed a significant improvement in FCR as compared to the chicks fed the control diet. The addition of citric acid to a broiler diet improved feed efficiency, and the results implied that the beneficial effects of citric acid was on feed conversion (Nezhad et al., 2007).
Feeding high level of rice bran $(60 \%)$ contributed to the high content of phytate in the feed by $4.14 \%$, because rice bran contained $6.9 \%$ of phytate. Phytate has affinity as a chelating agent on divalent ions of some minerals $(\mathrm{Ca}, \mathrm{Fe}, \mathrm{Cu}, \mathrm{Mn}$, and $\mathrm{Zn})$ and on protein, that will decrease the availability of such nutrients for growth in poultry. This condition could interfere with the body metabolism and resulted in low body weight gain. Phytate affected the digestibility of dietary protein and amino acids in poultry (Kurniawati \& Yuanita, 2014). The negative effects of phytate in rice bran could be eliminated by supplementation of lime juice, and the evidence of the process could be proved by the increased protein digestibility (Table 2). The increase in digested protein would then correlate with the increase in absorbed protein, which in turn increased body weight gain. Generally, ration composed of $20 \%$ rice bran or more could inhibit growth due to the presence of phytic acid, which formed complexes with protein, pectin, and starch or fiber polysaccharides. This would become an obstacle on protein and phosphorus digestion that finally affected nutrient utilization for growth. Supplementation of citric acid ( $30 \mathrm{~g} / \mathrm{kg})$ in corn-soybean based diet for chicken with low native phytase activity and supplementation of microbial phytase increased protein and phosphorus depositions, and growth performance (Sukria \& Liebert, 2004).

\section{CONCLUSION}

It could be concluded that the best nutrient utilization was achieved by T3 treatment, namely rice bran-based diet supplemented with $3 \mathrm{~mL}$ lime juice. Supplementation of lime juice with a higher level in male Pelung chicken could enhance the nutrient digestibility and finally resulted in the increased of body weight gain and improved feed conversion ratio.

\section{REFERENCES}

Abd El-Hakim, A. S., G. Cherian, \& M. N. Ali. 2009. Use of organic acid, herbs and their combination to improve the utilization of commercial low protein broiler diets. Int. J. Poult. Sci. 8: 14 -20. http://dx.doi.org/10.3923/ ijps.2009.14.20

Abdel-Fattah, S. A., M. H. El-Sanhoury, N. M. El-Mednay, \& F. Abdel-Azeem. 2008. Thyroid activity, some blood constituents, organs morphology and performance of broiler chicks fed supplemental organic acids. Int. J. Poult. Sci. 7: 215-222. http://dx.doi.org/10.3923/ijps.2008.215.222

Van Antwerpen, P., F. Dufrasne, M. Lequeux, K. Z. Boudjeltia, I. Lessgyer, S. Babar, P. Moreau, N. Moguilevsky, M. Vanhaeverbeek, J. Ducobu, \& J. Nève. 2007. Inhibition of the myeloperoxidase chlorinating activity by nonsteroidal anti-inflammatory drugs: flufenamic acid and its 5-chloro-derivative directly interact with a recombinant human myeloperoxidase to inhibit the synthesis of hypochlorous acid. Eur. J. Pharmacol. 570: 235-43. http://dx.doi. org/10.1016/j.ejphar.2007.05.057

Barrett, N. E., A. S. Grandison, \& M. J. Lewis. 1999. Contribution of the lactoperoxidase system to keeping quality of pasteurized milk. J. Dairy Res. 66: 73-80. http://dx.doi. org/10.1017/S0022029998003252

Biswas, N., P. Balac, S. K. Narlakanti, M. D. E. Haque, \& M. D. 
M. Hassan. 2013. Identification of Phenolic Compounds in Processed Cranberries by HPLC Method. J. Nutr. Food Sci. 3: 1-5. http://dx.doi.org/10.4172/2155-9600.1000181

Deepa, C., G. P. Jeyanthi, \& D. Chandrasekaran. 2011. Effect of phytase and citric acid supplementation on the growth performance, phosphorus, calcium and nitrogen retention on broiler chicks fed with low level of available phosphorus. Asian J. Poult. Sci. 5: 28-34. http://dx.doi.org/10.3923/ ajpsaj.2011.28.34

Ghazalah, A. A., A. M. Atta, K. Elkloub, M. E. L. Moustafa, Riry, \& F. H. Shata. 2011. Effect of dietary supplementation of organic acids on performance, nutrients digestibility and health of broiler chicks. Int. J. Poult. Sci. 10: 176-184. http://dx.doi.org/10.3923/ijps.2011.176.184

Gunal, M., G. Yayli, O. Kaya, N. Karahan, \& O. Sulak. 2006. The effects of antibiotic growth promoter, probiotic or organic acid supplementation on performance, intestinal microflora and tissue of broiler. Int. J. Poult. Sci. 5: 149-155. http://dx.doi.org/10.3923/ijps.2006.149.155

Hidayat, C., Sumiati, \& S. Iskandar. 2014. Growth responses of native chicken Sentul G-3 on diet containing high ricebran supplemented with phytase enzyme and ZnO. JITV 19: 193-202.

Huyghebaert, G. 2005. Alternatives for antibiotics in poultry. In: N. Zimmermann (Ed). Proceedings of the 3rd Mid-Atlantic Nutrition Conference. Pp. 36-57.

Indreswari, R., H. I. Wahyuni, N. Suthama, \& P. W. Ristiana. 2009. Calcium utilization for egg shell formation in laying hens due to the different feeding regimes of morning and afternoon portion. JITAA 34: 134-138.

Iqbal, S., T. G. Kazi, M. I. Bhanger, M. Akhtar, \& R. A. Sarfraz. 2008. Determination of selenium content in selected Pakistani foods. Int. J. Food Sci. Technol. 43: 339-345. http:// dx.doi.org/10.1111/j.1365-2621.2006.01447.x

Kurniagung, F., V. D. Y. B. Ismadi, \& I. Estiningdriati. 2012. The effect of adding lime in the ration of total lactic acid and coliform bacteria in digestive tract of Ducks Magelang male. Anim. Agric. J. 1: 405-413.

Kurniawati, Y. R. \& L. Yuanita. 2014. Pengaruh asam sitrat dan fitase Bacillus subtilis HG pada jagung (Zea mays L.) terhadap biovailabilitas mineral Ca (in-vitro). J. Chem. 3: 96-102.
Maghfiroh, K., I. Mangisah, \& V. D. Y. B. Ismadi. 2012. Pengaruh penambahan sari jeruk nipis (Citrus aurantifolia) dalam ransum terhadap kecernaan protein kasar dan retensi nitrogen pada itik magelang jantan. Anim. Agric. J. 1: 669-683.

Malkoski, M., S. G. Dashper, N. M. O. B. Simpson, G. H. Talbo, M. Macris, K. J. Cross, \& E. C. Reynolds. 2001. Kappacin, a novel antibacterial peptide from bovine milk. Antimicrob. Agents Chemother. 45: 2309-2315. http://dx.doi. org/10.1128/AAC.45.8.2309-2315.2001

Martinez-Ameaqua, C., C. M. Parsons, \& D. H. Baker. 2006. Effect of microbial phytase and citric acid on phosporus bioavability, apparent metabolizable enegy and amino acid digestibility in distiller dried grains with solubles in chicks. Poult. Sci. 85: 470-475. http://dx.doi.org/10.1093/ ps $/ 85.3 .470$

Mohamed, C., K. A. Clementine, M. Didier, L. Gérard, \& D.C. Marie Noëlle. 2013. Antimicrobial and physical properties of edible chitosan films enhanced by lactoperoxidase system. Food Hydrocoll. 30: 576-580. http://dx.doi. org/10.1016/j.foodhyd.2012.07.018

Nezhad, Y. E., M. Shivazad, M. Nazeeradl, \& M. M. S. Babak. 2007. Influence of citric acid and microbial phytase on performance and phytate utilization in broiler chicks fed a corn-soybean meal diet. J. Fac. Vet. Med. 61: 407-413.

Onyeagba, R. A., O. C. Ugbogu, C. U. Okeke, \& O. Iroakasi. 2004. Studies on the antimicrobial effects of garlic (Allium sativum linn). Ginger (Zingiber officinale roscoe) and lime (Citrus aurantifolia linn). Afr. J. Biotechnol 3: 552-554. http://dx.doi.org/10.5897/AJB2004.000-2108

Rafacz-Livingston, K. A., C. M. Parsons, \& R. A. Jungk. 2005. The effects of various organic acids on phytate phosphorus utilization in chicks. Poult. Sci 84: 1356-1362. http://dx.doi. org/10.1093/ps/84.9.1356

Ridwan, R., S. Ratnakomala, G. Kartina, \& Y. Widyastuti. 2005. Pengaruh penambahan dedak padi dan Lactobacillus plantarum 1BL-2 dalam pembuatan silase rumput gajah (Pennisetum purpureum). Med. Pet. 28: 117-123.

Sukria, H. A. \& F. Liebert. 2004. Citric acid and microbial phytase inclusion in the diet to improve utilization phytate phosporus and growth of broiler. Med. Pet 27: 21-24. 